\title{
STUDIES ON ADRIAMYCIN SIDE EFFECTS ON THE RENAL FUNCTION AND MORPHOLOGY IN RATS
}

By

\author{
El.Gindy, M., Gamil, T. and Sirag, S.
}

From

General Surgery and Pathology Departments,

Mansoura Faculty of Medicine 1991

Received for Puplication : 15/10/1990

\section{INTRODUCTION}

Adriamycin (ADR) is an anthracyclic antibiotic (Di Marco et al., 1969). It is considered now to be a very effective and useful chemotherapeutic agent in the treatment of many human solid tumors and malignant heamatological processes (Carter et al., 1972). However, its extensive use at doses adequate for effective antitumor therapy is restricted by the appearance of a severe cardiotoxicity (Adamson, 1974; Bristow et al., 1978; and Nagineni, 1985). Little is known about the effect of ADR on the kidney function and its relation to any pathological changes. Our study aims to reveal this relation after 4 and 8 weeks of ADR treatment.

\section{Materials and methods}

Animals: Experiments were carried out on white male rats weighing be- tween 200-300 grams. They were allowed acess to food and water ad. libitum. Five rats were injected i.v. with normal saline twice/week (served as control), and twinty rats arranged in two groups underwent treatment with adriamycin ( $1 \mathrm{mg} / \mathrm{kg}$ b.w. twice/week i.v.) for four weeks and eight weeks respectively. Urine samples were collected over 24 hours period from control and adriamycin treated groups by using metabolic cages. Then the animals were sacrified for sampling analysis.

Biochemical and histochemical investigations :

Serum and urinary creatinine were determined by the method of Whiting et al., 1982. Creatinine clearance was calculated applying the following formula : Clearance $=(P \times V / u) \mathrm{m} / \mathrm{min}$.

where $\mathbf{P}$ is the plasma concentration ( $\mathrm{mg} / 100 \mathrm{ml}$ )

MANSOURA MEDICAL JOURNAL 


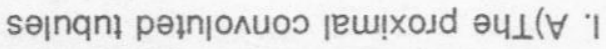

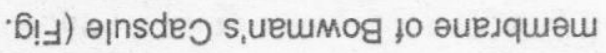

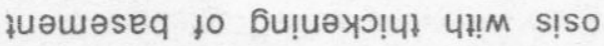

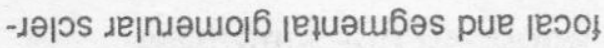
mous słed pałead u!okue! ło sরeu

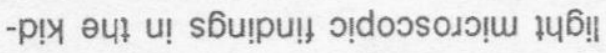

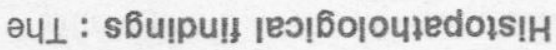

łueग!!!u6! łou SEM

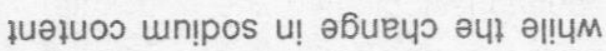

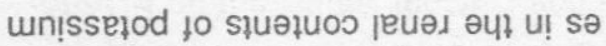

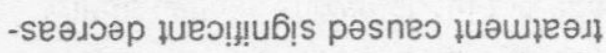

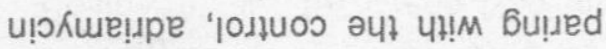

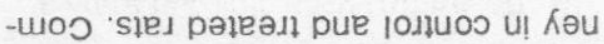
-p!्र әцł 10 słuәџu०o $(X)$ un!̣sełod pue

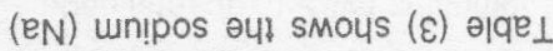

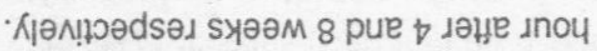

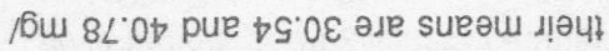
әләчм чи!ч Кал әләм (乙 $6 !\rfloor)$ sıед рә

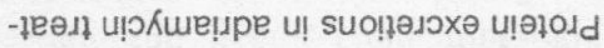

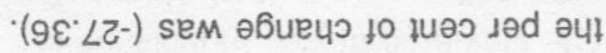

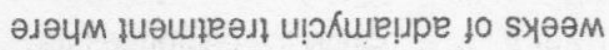

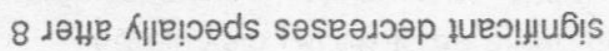

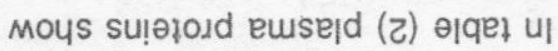

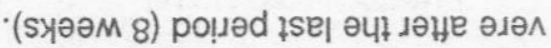

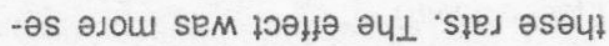

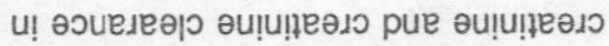

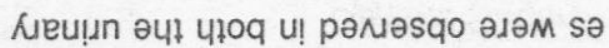
-seәдэәр џиеэ!!

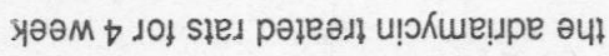
10 әu!̣!ןеәдо eusejd әцł u! sәseәdо

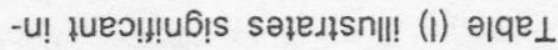

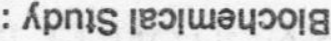

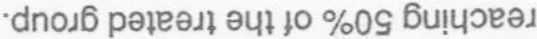
รуәәм 8 дәло dnoג6 рәюеәд и!экие

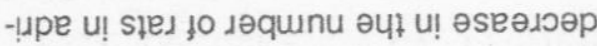

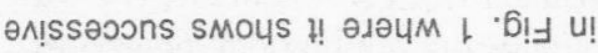

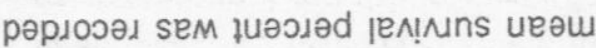

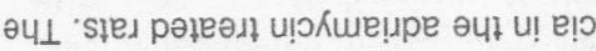
-ədo|e ןessopp!u pue ә!! ədde Ło ssol

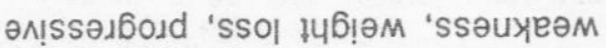

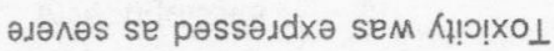

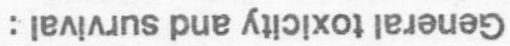

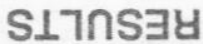

$\triangleright 961$

'uos6!!as pue sauњəz to poutaw

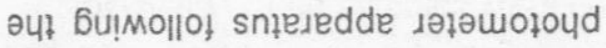
- oגłəads uo!̣diosq

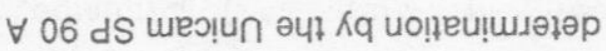
un!ssełod pue un!̣pos 101 pajedald

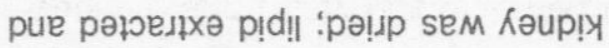

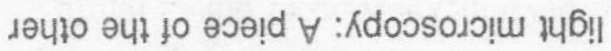

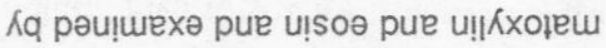

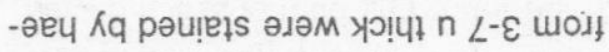
suo!̣oes U!ңeded u! pәppeque pue uo!̣njos u!ןewnol \%०। u! pex!! :uo!!

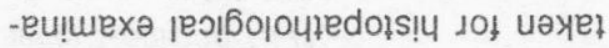

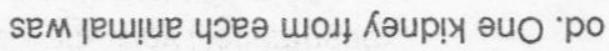

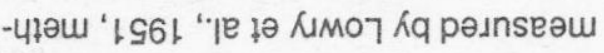
әдәм su!əıаd Kueu!n pue unas

(ן⿲丿丨 00 t

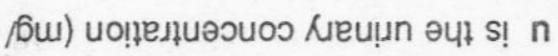

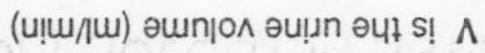


show cloudy swelling (Fig.l.c ). $40 \%$ of the treated animals show dilated collecting tubules with eosinophilic red casts in their lumens (Fig.I.D). $60 \%$ show, focal interstitial inflammation and fibrosis (Fig.1.A). The mentioned pathological findings are seen in both treated groups, but more marked in 8 weeks treated one.

\section{DISCUSSION}

The fact that the antitumor antibiotic adriamycin has a glycosidic structure which resembles some glycosides with cardiotoxic effect, and the fact that cardiomyopathy induced by chronic intoxication with adriamycin present very marked alterations in $\mathrm{Na}$ and $\mathrm{K}$ contents (Olson, 1974) promoted us to study the effect of this drug on the kidney function and morphology and their relation to the $\mathrm{Na}$ and $\mathrm{K}$ contents of the kidney.

\section{Biochemical studies :}

In the present; work the results showed significant decrease in $\mathrm{K}$ content, but not any significant change in $\mathrm{Na}$ content in the kidney in all adriamycin treated rats. These results can be interpreted by the preliminary studies of Gosalvez et al., 1979 who showed that adriamycin is a potent inhibitor of
Na-K ATP ase of native heart microsomes and inhibits K-transport (although not Na-transport) in slices of kidney cortex. In contrast; Richard et al., 1987 found that, the reduction in renal blood flow in adriamycin treated rats contributes to sodium and water retention. An intriguing result is the finding that adriamycin causes a nearly complete inhibition of $\mathrm{K}$ reaccumulation while failing to affect Naextrusion. The explanation may be that the drug has uncoupled the sodium transport aspects of the system from its dependency on $\mathrm{K}$. This would represent a novel inhibitory effect in ion transport (Gosalvez et al., 1979).

Creatinine is a substance that has a maintained plasma level by its continuous endogenous production due to muscle catabolism and is indirectly affected by diet. Given a constant rate of production, and for negligible tubular reabsorption and extra renal losses, the plasma level of creatinine depends directly on the GFR and considered to be a good index of the degree of impairment of GFR. All adriamycin treated rats has developed nephrotoxicity by the time of study as judged by an increased plasma creatinine and decreased its concentration in the urine (Table 1), thus leading to 


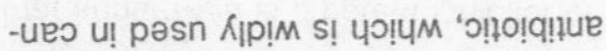

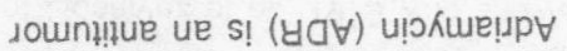

\section{A $4 \forall$ WWnS}

uo!̣ounț Kəu

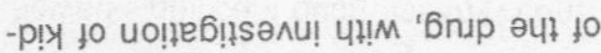

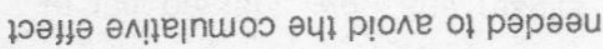

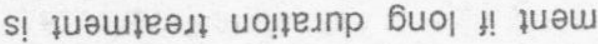

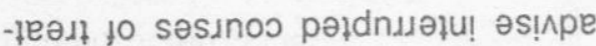

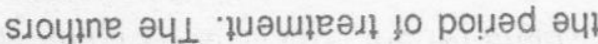

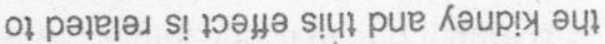

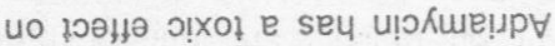

\section{: uolsnjouos}

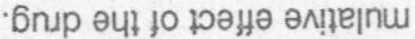

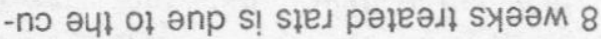
'suo!s

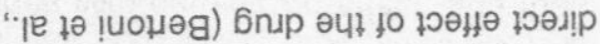

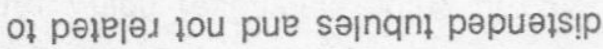

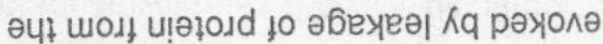

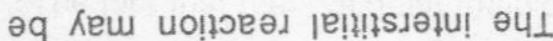

'६86! '!zznuay

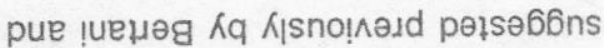

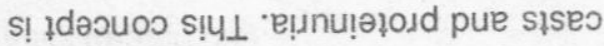

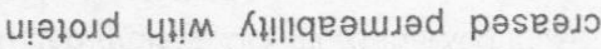

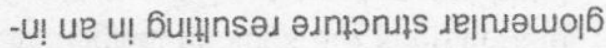

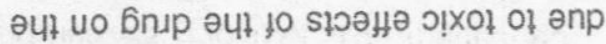

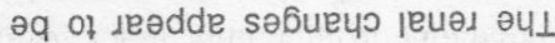

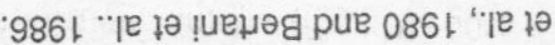
иечо чи!м ұиәшәәдбе u! әле sбu!pu!!

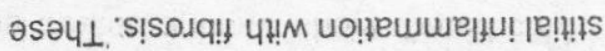

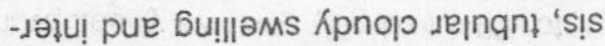

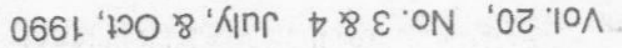

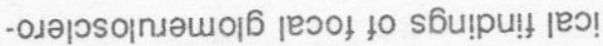
-6olouted әul Kq pau!ejdxә әq ueo słed

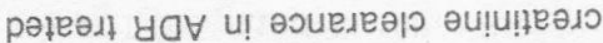

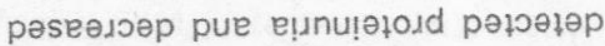

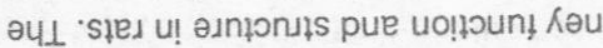
-p!x u! sә6uец प1!m e!

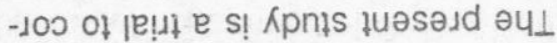

\section{: s6u!pu!! ןeग!6ојоцłеd}

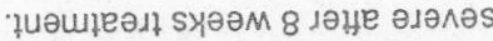

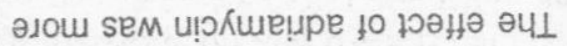

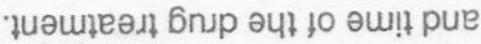

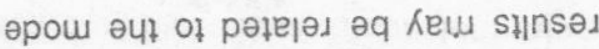

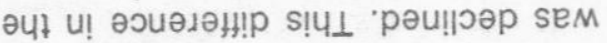

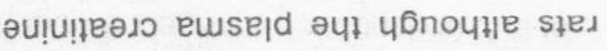
ןodłuos u! punol sanjes әцा wod, tuә

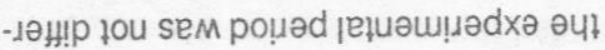

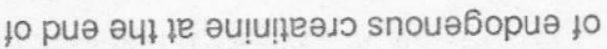
әоиедеәр se pәдnseәш

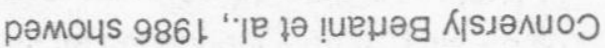

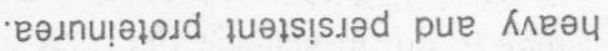
to әtełs e słed u! səlowodd u! Kkur!ppe

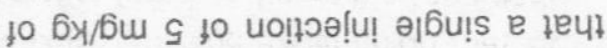

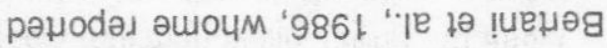
pue ؛ $\varepsilon 86 \vdash$ '!zznuəy pue !uenәg to

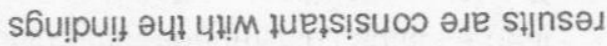

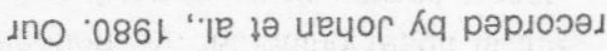

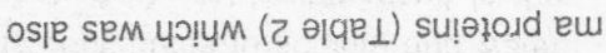

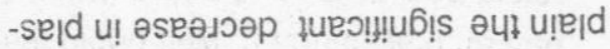

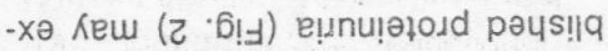

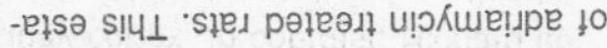

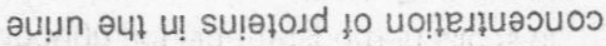
чбі̣ рәјеәлал osje sł!nsad цuәsadd

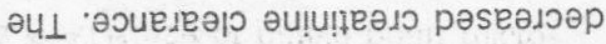


cer chemotherapy. Previous studies revealed cases of heavy proteinuria following single injection of $5 \mathrm{mg} / \mathrm{kg}$ ADR. Marked alteration in sodium and potassium contents were seen in cases of cardiomyopathy induced by chronic intoxication with ADR. We are interesting to study the relationship between renal sodium and potassium contents and proteinuria, in adriamycin treated rats ( $1 \mathrm{mg} / \mathrm{kg} \mathrm{b}$.w. twice a week for 4 and 8 weeks), and the renal function and morphology. The results showed impaired renal function as revealed by the significant increase in plasma creatinine and decreased urinary creatinine and creatinine clearance in ADR treated rats. ADR treat- ment also produced significant decrease in plasma proteins and proteinuria . Sodium content of the kidney was not significantly changed, while potassium content was significantly decrease in ADR treated rats. These finding are consistant with the pathological examination which show glomerular sclerosis, cloudy swelling of the proximal convoluted tubules, dilated collecting tubules with protein casts and inflammation of the interstitial tissue. These changes are more marked in 8 weeks ADR treated rats. The study advise interrupted courses of ADR in the long treatment periods. with investigations for the kidney function.

Table (I) : Plasma (P) and urinary (U) creatinine $n$ mg/ , and creatinine clearance (C) in $\mathrm{mi}$ minute, in control and adriamycin treated rats.

\begin{tabular}{|c|c|c|c|c|c|c|c|c|c|}
\hline & \multirow{2}{*}{\multicolumn{3}{|c|}{ Control }} & \multicolumn{6}{|c|}{ Adriamycin (1mg/kg) } \\
\hline & & & & \multicolumn{3}{|c|}{4 weeks } & \multicolumn{3}{|c|}{8 weeks } \\
\hline & $\mathrm{P}$ & $U$ & C & $P$ & $U$ & C & $P$ & $U$ & C \\
\hline Mean & 7.26 & 304.6 & 0.51 & 7.80 & 246.80 & 0.43 & 9.60 & 182.60 & 0.35 \\
\hline \pm S. E & 0.08 & 1.66 & 0.006 & $0.06^{*}$ & $1.78^{\circ}$ & $0.008^{\circ}$ & $0.11^{\circ}$ & $1.76^{\circ}$ & $0.008^{*}$ \\
\hline$\%$ of change & & & & +7.44 & -18.98 & -15.69 & +32.23 & -40.05 & -31.37 \\
\hline
\end{tabular}

$n=5$

- = Significantly different from controi $(P<0.005)$. 


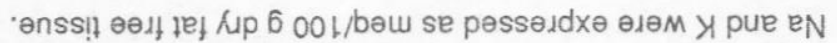
. $\left(9000^{\circ}>\right.$ d) ן0.1

$\mathrm{s}=\mathrm{u}$

\begin{tabular}{|c|c|c|c|c|c|c|}
\hline$\angle 6^{\circ} \varepsilon Z^{-}$ & $99^{\circ} L^{-}$ & $9 \varepsilon$ ๑レー & $89^{\circ} 0^{+}$ & & & өбиечว 10 \% \\
\hline$* \angle Z^{\prime} O F$ & $82^{\circ} 0^{\mp}$ & $* \neg \varepsilon^{\circ} 0^{\mp}$ & $\angle Z O^{F}$ & $\triangleright Z^{\circ} O^{\mp}$ & $\nabla D^{\prime}{ }^{\mp}$ & $\exists S^{\mp}$ \\
\hline$\nabla \nabla 62$ & 2202 & 9เ'ย & $89^{\circ} 02$ & ZL'8E & $9 S^{\circ} 02$ & ueew \\
\hline X & EN & X & EN & X & EN & \\
\hline \multicolumn{2}{|c|}{ รуәәМ 8} & \multicolumn{2}{|c|}{ syәәм $\nabla$} & \multirow{2}{*}{\multicolumn{2}{|c|}{ jodiuos }} & \\
\hline \multicolumn{4}{|c|}{ 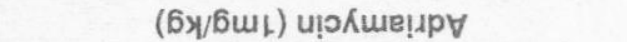 } & & & \\
\hline
\end{tabular}

-sied pejeedt

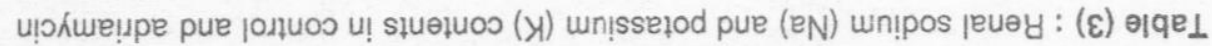

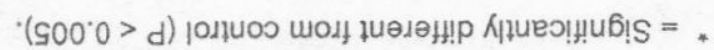

$\mathrm{g}=\mathrm{u}$

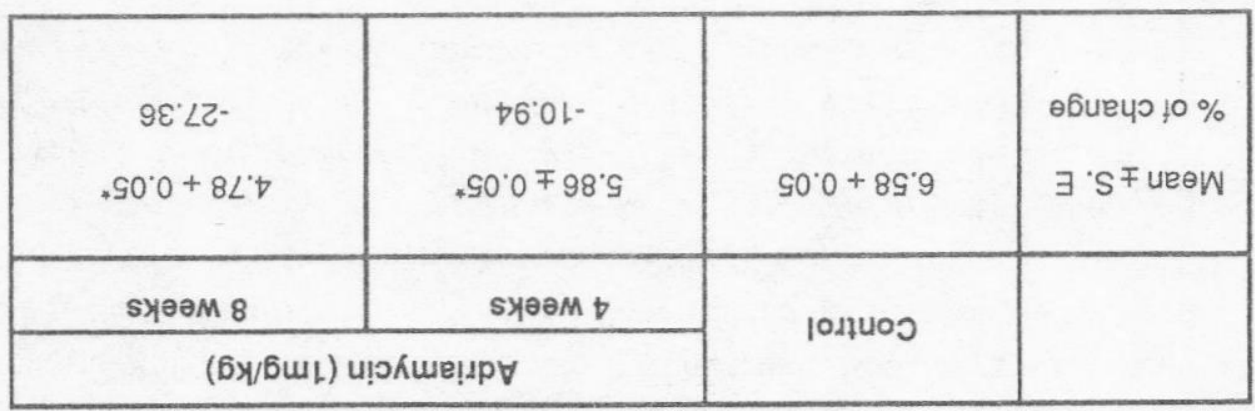

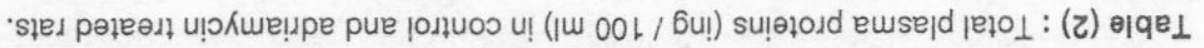


El-Kholy, W. M et al....

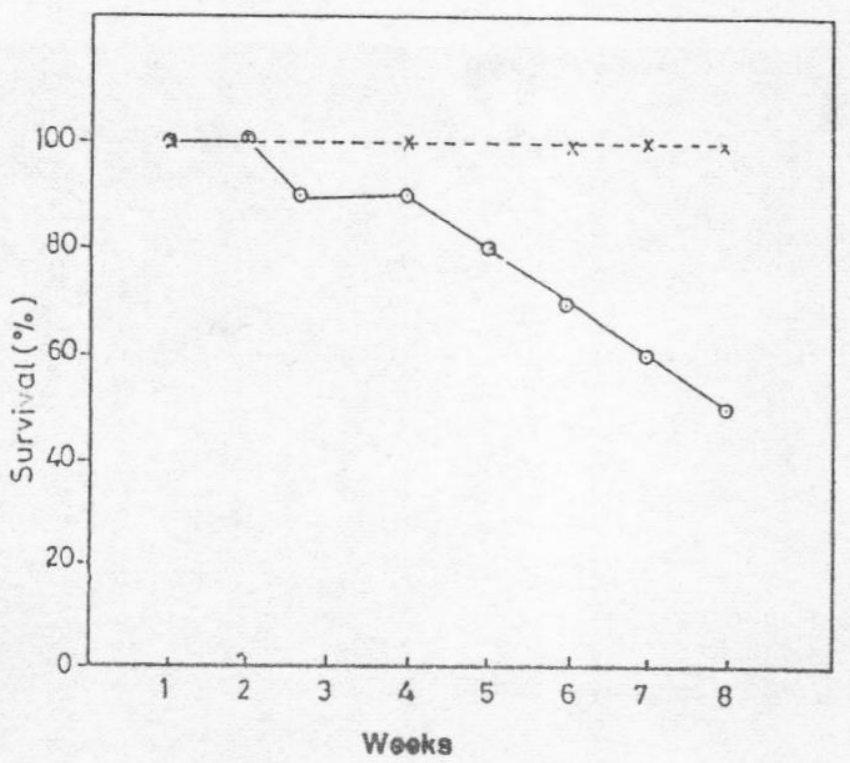

Fig. 1 : Effect of adrlamycin on the survlvat percent in white rats.

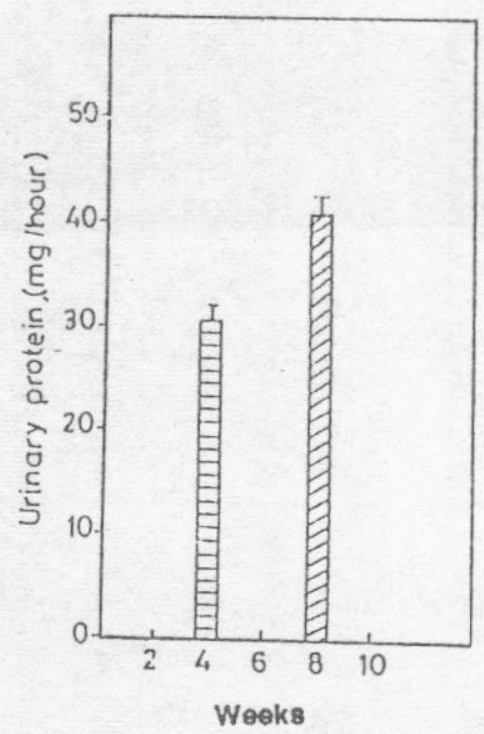

Fig. 2 : Protein excretion in adriamycin treated rats results are expressed as mean \pm SD. 
วueسุeed?

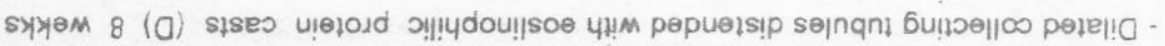

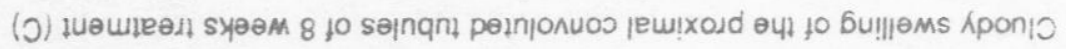

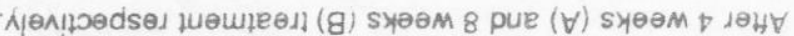

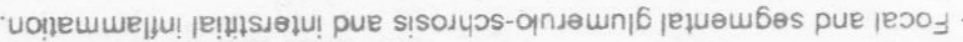

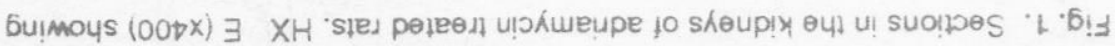

$0 \cdot 1$

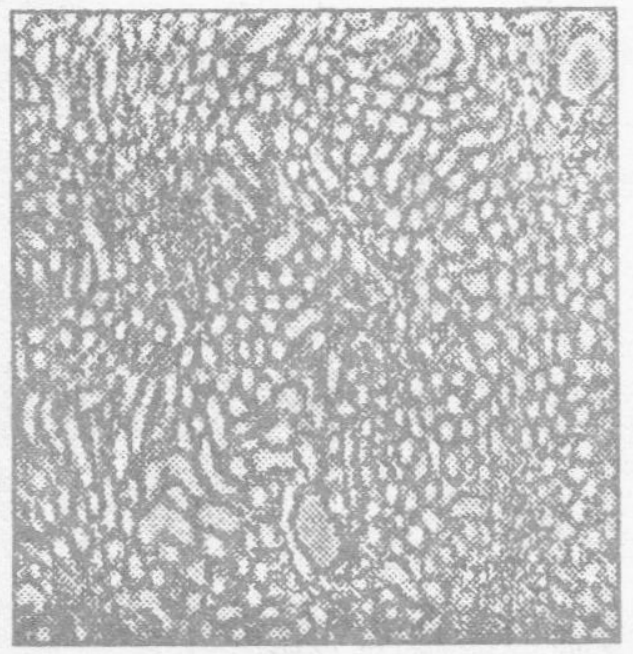

$0 \%$

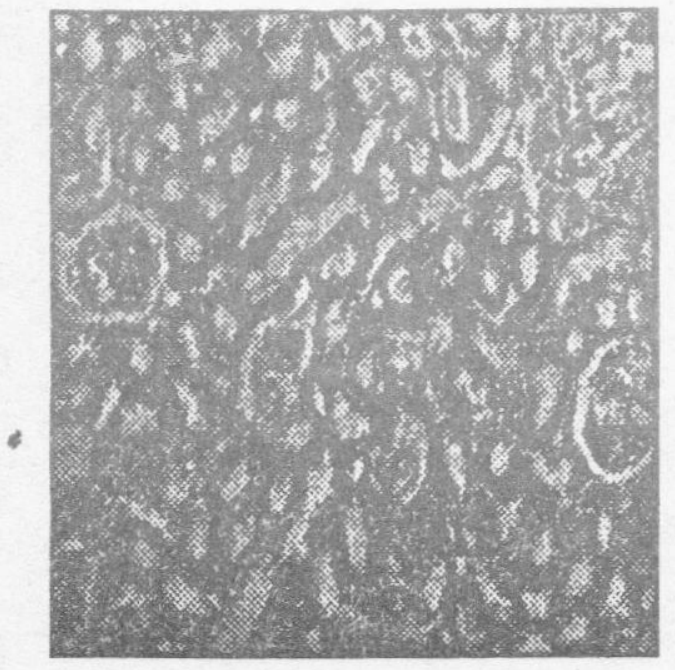

g '

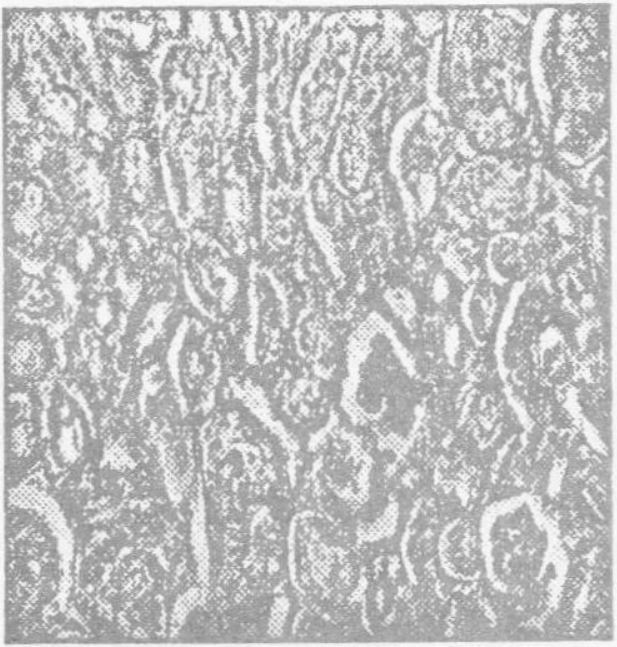

$\forall \cdot$

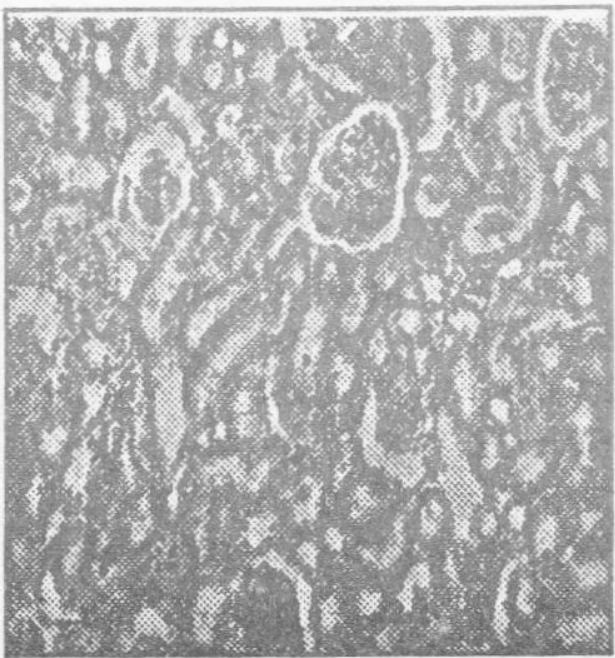




\section{REFERENCES}

Adamson, R.H. (1974) : Cancer chemotherapy Rep., 58 : 93.

Bertani, T., Remuzz G. (1983) : Epithelial cell damage, in glomerular injury: 300 years after Morgagni. edited by Bertani T. Remuzzi G. Milano, Wichtig Editore, 1983, p. 163.

Bertani, T., Cutillo, F., Zoja C.; Brogginı M. and Remuzzi 6., (1986) : Kidney International, Vol. 30, pp. 488-496.

Bristow, M. R., Mason, J. W., Billingham, M. E., and Danleis, J. R., (1978): Ann. Intern. Med., 88: 169175.

Carter, S. K., Di Marco, A., Ghione, M.; Krakoff, I. H., and Mathe, G. (1972) : International Symposium on adriamycin. Part Y. Clinical activity and side effects, pp 135-248. New York : Springer-Verlag.

Di Marco, A., Gaetani, M. and Scarptinato, B. (1969) : Cancer Chemotherapy Rept., 53: 33-37.

Gosalvez, M., George D. V. Van Rossum, and Mary F.
Blanco. (1979) : J. Cancer Research, 39 : 257 261.

Johan G. S. Breed, Ariaen N. E. Zimmerman, Jan A. M. A. Dormans, and Herbert M. Pinedo. (1980) : Cancer Research, Vol. $40: 2033-2037$.

Lowry, O. H., Rosebrough, N. J.; Farr, A.L. and Randall, R. J. (1951) : J. Biol. Chem. 193: 265.

Nagineni, Chandrasekharam N., Takenori Yamada, Jing J. Yang and Maria W. Seraydarian (1985): Res. Commun Chem. Pathol. Pharmacol. 50(2): 301-304.

Richard B. Wanless, Inder S. Anand, Jane Gurden, Peter Harris and Philip A. Poole-Wilson (1987) : J. of Pharm. and Exper. Therap. 243 (3) : 1101.

Whiting, P. H., Thomson, A. V. P. Blair, J. T. and Simpson, J. G. (1982) : Br. J. Exp. Path. $68: 88$

Zettner and Seligson (1964) : Quoted from Hawk's Physiological Chemistry 12th Edition, J. and A Churchill Ltd. London, p. 1008.

MANSOURA MEDICAL JOURNAL 


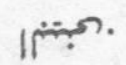

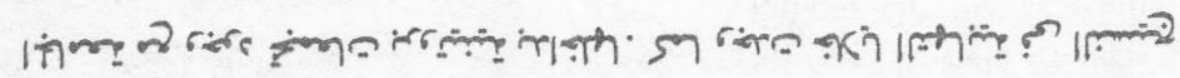

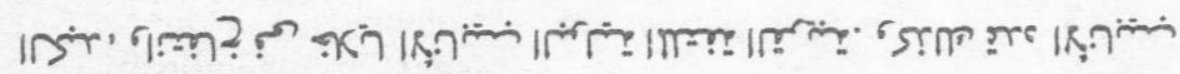

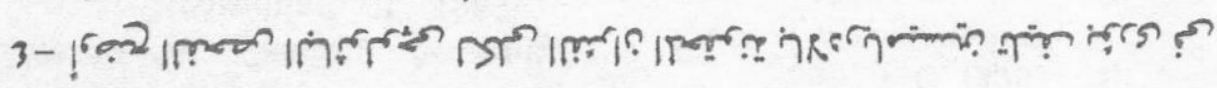

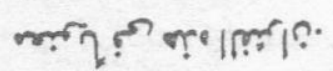

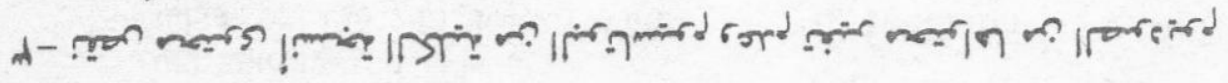
min?

7IIז

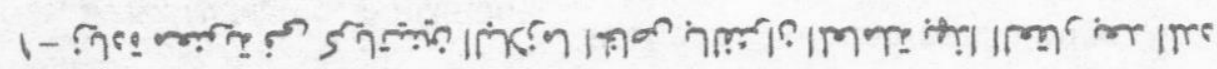
ทศึก:-

3 ! 3 ग

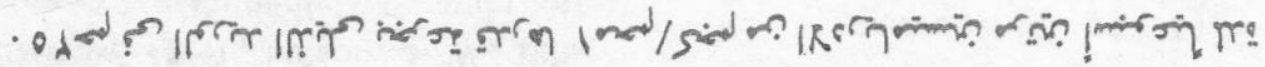
|

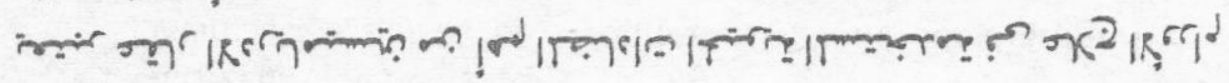

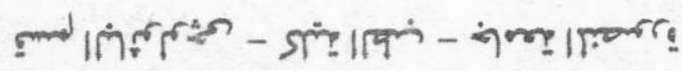

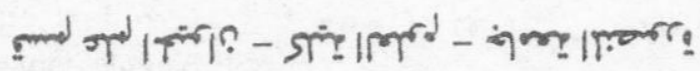

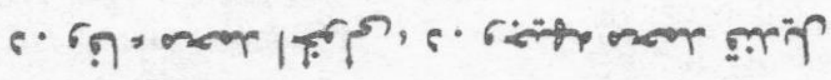

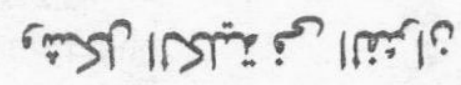

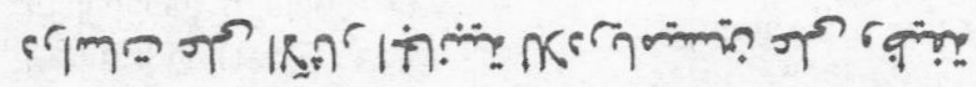

iman

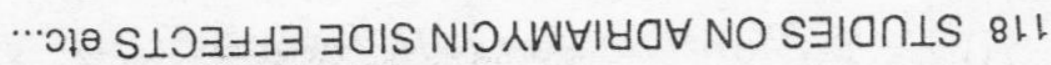

